\title{
The Effect of Training, Position Promotion, and Mutation on Employee Performance in PT. Transfashion Indonesia
}

\author{
Nopri Ariansyah \\ Narotama Uiversity, Indonesia \\ ariansyah_nopri@yahoo.com
}

\begin{abstract}
Human resources are needed in obtaining company success. This study aims to determine the effect of training, promotion and mutation on employee performance in Surabaya. The type of research used by a sample of 50 employees of PT. Transfashion Indonesia, which works out the questionnaire, is all employees. The data analysis technique used is multiple linear regression analysis. The results of the study show that training, promotion and mutation simultaneously influence the performance of employees in Surabaya. As well as training, job promotion and mutations have a partial effect on employee performance in Surabaya. The higher the training, promotion and transfers are, the higher the employee's performance.
\end{abstract}

Keywords: Job Training, Position Promotion, Employee Mutation, Employee Performance

\section{INTRODUCTION}

Retail is one or more activities that add value to products and services to consumers both for family needs or for personal needs. Many people think that Alfamart / Indomart is a real retailer. Even though doing business in the retail world is very interesting because it requires precision. There is even a slogan that says "retail is detail". This slogan indicates that people who want to be involved in the retail world must be people who want to work hard, be creative, and detail in every activity. Retail is not always related to the daily needs that are usually sold at Alfamart / Indomart. For example, Premium Hut, McD and KFC are examples of successful food retailers.

The market is getting narrower but more retailers are standing. One result of this is a price war that cannot be avoided. Retailers tend to think of efficiency, especially in place investment and other fix-costs. It was during this time that e-commerce was being funny, where the growth of smart phones and the use of other gadget devices grew very dramatically.

Trans Fashion is a retail company in Indonesia that is the owner of a Trans Lifestyle subsidiary. CT Corp acquired a majority stake in Mahagaya Perdana in 2007 and changed its name to Trans Fashion company. Trans Fashion is a leading high-end fashion retailer in Indonesia with more than 25 international high-end brands such as Hugo Boss, Etienne Aigner, Tods, Versace, Tommy Hilfiger, Valentino, Brioni, Jimmy Choo, Furla, Giorgio Armani, Salvatore Ferragamo, Furla, Geox, etc.

A phenomenon in the effect of training on employee performance often postponing work and not being able to complete tasks assigned by the boss on time, this can be seen from the performance that is not finished in accordance with the standard operating procedures,does not use leisure time well and often prioritizes counter-productive matters, such as more chatting and holding a meal together outside the office or in the office,employees who are less passionate about work that causes productivity to decrease so that it adversely affects the company itself.

Research that has been carried out by researchers before requires it to be done again in order to aim to strengthen the research produced by the previous one. The purpose of this study was to analyze the effect of partial and partial effects of training variables, job promotion variables, mutation variables on the performance of employees of PT. Transfashion Indonesia in Surabaya.

\section{LITERATURE REVIEW}

\section{Job Training}


It is also explained that training is a part of education that involves the learning process to acquire and improve skills outside the applicable education system in a relatively short time and with methods that prioritize practice rather than theory (Ardana et al, 2012).

\section{Promotion Promotion}

Irham Fahmi's(2016: 88) Promotion is an increase in the position of an employee from a previous position to a higher position, the promotion can be in the form of a promotion from a low to a higher position. Ardana (2012: 107) there are several criteria that need to be considered by companies in promoting their employees, namely: Seniority, educational qualifications, work performance, initiative and creativity, level of loyalty, honesty and supelitas.

\section{Employee Mutation}

Hasibuan(2012). This mutation must be based on the achievement index that can be achieved by the employee concerned. Mutation is intended to get in the right place, with the intention that the employee / member concerned gets a new atmosphere and job satisfaction as high as possible and can show even higher achievements.

\section{Performance Employee}

Performance According to Mangkunegara (2002: 67) in Pasolong (2010: 176) performance is the result of work in quality and quantity achieved by someone in carrying out their functions in accordance with the responsibilities given to him.

\section{Inter-Variable}

\section{Relationships with Employee Performance}

Training is conducted for new employees to be able to carry out new tasks that are charged and for old employees to improve the quality of the implementation of their present and future tasks. It was also explained that training is a part of education that involves the learning process to acquire and improve skills outside the applicable education system in a relatively short time and with methods that prioritize practice rather than theory (Ardana et al. 2012). Siagian (1995: 227) defines performance as a person's overall ability to work in such a way as to achieve work goals optimally and various targets that have been created with sacrifices which are smaller in ratio than the results achieved.

\section{Relationship between Position Promotion with Employee Performance}

Irham Fahmi (2016: 88) Promotion is an increase in the position of an employee from a previous position to a higher position, the promotion can be in the form of a promotion from a low to a higher position. Ardana (2012: 107) there are several criteria that need to be considered by companies in promoting their employees, namely: Seniority, educational qualifications, work performance, initiative and creativity, level of loyalty, honesty and supelitas.

\section{Relationship of Mutations with Employee Performance}

Mutation is a change in position / position / place / work performed both horizontally and vertically (promotion) within an organization. Hasibuan (2012). This mutation must be based on the achievement index that can be achieved by the employee concerned. Mutation is intended to get in the right place, with the intention that the employee / member concerned gets a new atmosphere and job satisfaction as high as possible and can show even higher achievements.

\section{Hypothesis}

Hypothesis is a conjecture while the truth is still to be tested. Based on the research concept framework above, the researcher can conclude the hypothesis that will be tested in this study are as follows :

H1: (X1) training has a significant effect on (Y) employee performance

$\mathrm{H} 2$ : (X2) job promotion has a significant effect on (Y )employee performance

H3: (X3) mutations with a significant effect on (Y)employee performance

$\mathrm{H} 4$ : (X1, X2, X3) training, promotion, mutations have an effect on (Y) employee performance

\section{RESEARCH METHODS}


Quantitative research is a research method which uses the process of data in the form of numbers as a tool for analyzing and conducting research studies, especially regarding what has been studied (Kasiram, 2008). According to Sukmadinata (2011: 250), "Population is a large group and the area that becomes the scope of our research." According to Arikunto (2002: 108), "Population is the whole subject of research. for the population of 50 employees. All members of the population, amounting to 50 employees, were selected by census technique with 50 employees as samples.

\section{DATA ANALYSIS AND DISCUSSION}

Quantitative analysis

The quantitative research method is a research method based on the philosophy of positivism, used to examine certain populations or samples, sampling techniques are generally carried out randomly, data collection uses research instruments, quantitative / statistical data analysis with the aim of to test the hypothesis set by Sugiyono (14: 2015).

\section{Validity}

\begin{tabular}{|r|r|r|r|r|}
\hline & $\begin{array}{c}\text { Scale Mean if } \\
\text { Item Deleted }\end{array}$ & $\begin{array}{c}\text { Scale Variance if } \\
\text { Item Deleted }\end{array}$ & $\begin{array}{c}\text { Corrected Item- } \\
\text { Total Correlation }\end{array}$ & $\begin{array}{c}\text { Cronbach's Alpha } \\
\text { if Item Deleted }\end{array}$ \\
\hline X11 & 41.5800 & 29.718 & .665 & .779 \\
X12 & 41.5200 & 34.785 & .191 & .821 \\
X13 & 41.4800 & 32.826 & .406 & .803 \\
X21 & 41.5800 & 29.718 & .665 & .779 \\
X22 & 41.5000 & 32.663 & .418 & .802 \\
X23 & 41.5000 & 32.663 & .418 & .802 \\
X31 & 41.5800 & 29.718 & .665 & .779 \\
X32 & 41.5200 & 34.785 & .191 & .821 \\
X33 & 41.5800 & 29.718 & .665 & .779 \\
Y1 & 41.6000 & 35.061 & .154 & .824 \\
Y2 & 41.5800 & 29.718 & .665 & .779 \\
Y3 & 41.5000 & 32.663 & .418 & .802 \\
\hline
\end{tabular}

From the results of the validity test above, it is known that all the validity values of each variable indicator are above the $\mathrm{R}$ table, which means that all questionnaire statements are declared valid.

\section{Test Reliability}

Reliability Statistics
\begin{tabular}{|r|r|}
\hline Cronbach's Alpha & N of Items \\
\hline .812 & 12 \\
\hline
\end{tabular}

From the results of the reliability test, the value of cronbach alpha is equal to .812 or greater than 0.60 , which means that the reliability test results in this questionnaire are declared reliable or reliable.

\section{CLASSICAL ASSUMPTION TEST Multicollinearity Test}

\begin{tabular}{|c|c|c|c|c|c|c|}
\hline & \multirow[t]{2}{*}{ Model } & \multicolumn{2}{|c|}{ Unstandardized Coefficients } & \begin{tabular}{|c|} 
StandardizedCoef \\
ficients \\
\end{tabular} & \multirow[t]{2}{*}{$\mathrm{t}$} & \multirow[t]{2}{*}{ Sig. } \\
\hline & & $\mathrm{B}$ & Std. Error & Beta & & \\
\hline \multirow[t]{4}{*}{1} & (Constant) & 1.252 & .774 & & 1.618 & .112 \\
\hline & Pelatihan & .476 & .162 & .466 & 2.934 & .005 \\
\hline & Promosi_jabatan & .267 & .085 & .342 & 3.127 & .003 \\
\hline & Mutasi & .140 & .085 & .189 & 1.634 & .109 \\
\hline
\end{tabular}

a. Dependent Variable: Kinerja_karyawan 


\begin{tabular}{|l|r|r|}
\hline \multicolumn{3}{|c|}{ Coefficientsa } \\
\cline { 2 - 3 } \multicolumn{1}{|c|}{ Model } & collinearityStatistics \\
\cline { 2 - 3 } & Tolerance & \multicolumn{1}{c|}{ VIF } \\
\hline (Constant) & & \\
Training & .171 & 5836 \\
Promosi_jabatan & .362 & 2,765 \\
Movements & .325 & 3,072 \\
\hline
\end{tabular}

a. Dependent Variable: Performance_employee

The regression model is said to be good if there is no correlation between the independent variables. To detect the presence or absence of multicollinearity in the reagression of factor or variance inlation values. If VIF is greater than 5, multicollinearity occurs. In the table above the multicollinearity test does not occur the symptoms of multicollinearity between each independent variable.

\section{Heteroscedasticity Test}

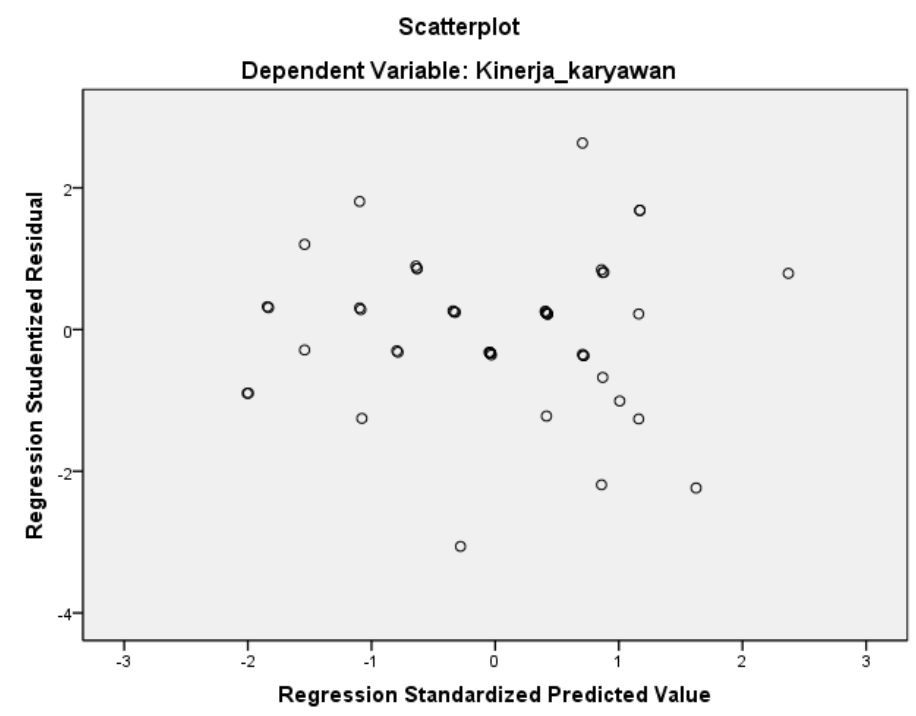

A regression model is said to detect heteroscedatasticity if scatter rises form a certain pattern that does not overlap one point with another.

\section{Normality Test}

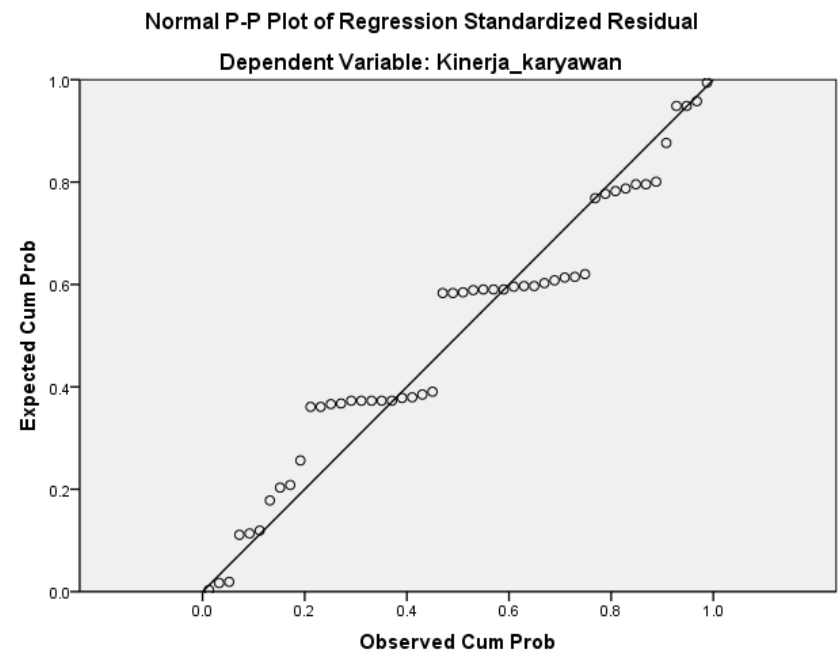

The results of the test data from the table above show that the data points spread not too far around the diagonal line. It could be said that the data in this study had a normal distribution. 
T Test (Partial Test)

Coefficients $^{\mathrm{a}}$

\begin{tabular}{|ll|r|r|r|r|r|}
\hline \multirow{2}{*}{ Model } & \multicolumn{2}{|c|}{ Unstandardized Coefficients } & $\begin{array}{c}\text { StandardizedC } \\
\text { oefficients }\end{array}$ & \multirow{2}{*}{$\mathrm{t}$} & \multirow{2}{*}{ Sig. } \\
\cline { 2 - 5 } & \multicolumn{1}{|c|}{$\mathrm{B}$} & Std. Error & \multicolumn{1}{c|}{ Beta } & & \\
\hline \multirow{2}{*}{1} & (Constant) & 1.252 & .774 & & 1.618 & .112 \\
& .476 & .162 & .466 & 2.934 & .005 \\
& Pelatihan & .267 & .085 & .342 & 3.127 & .003 \\
& Promosi_jabatan & .140 & .085 & .189 & 1.634 & .109 \\
\hline
\end{tabular}

a. Dependent Variable: Kinerja_karyawan

From the above coefficients table, the results of partial hypothesis testing are obtained as follows:

1. Effect of training variables (X1) on employee performance $(\mathrm{Y})$, analysis results obtained significant value 0.005 (greater than 0.05 ) means training variable (X1) has significant influence on employee performance $(\mathrm{Y})$.

2. The effect of job promotion variables (X2) on employee performance (Y), the results of the analysis obtained a significant value of 0.003 (greater than 0.05 ) means that promotion variables (X2) have a significant influence on employee performance $(\mathrm{Y})$.

3. The effect of mutation variables (X3) on employee performance (Y), the results of the analysis obtained a significant value of 0.109 (greater than 0.05 ) means that mutation variables (X3) have a significant effect on employee performance $(\mathrm{Y})$.

\section{F Test (Simultaneous Test)}

\begin{tabular}{|c|c|c|c|c|c|c|}
\hline \multicolumn{7}{|c|}{ ANOVA $^{\mathbf{b}}$} \\
\hline & Model & Sum of Squares & $\mathrm{df}$ & Mean Square & $\mathrm{F}$ & Sig. \\
\hline 1 & Regression & 89.754 & 3 & 29.918 & 61.643 & $.000^{\mathrm{a}}$ \\
\hline & Residual & 22.326 & 46 & .485 & & \\
\hline & Total & 112.080 & 49 & & & \\
\hline
\end{tabular}

a. Predictors: (Constant), Mutations, Promotion_ position, Training

b. Dependent Variable: Performance_Employee

Criteria in decision making in this test include:

1. Significant Value $<\alpha 0.05$ then $\mathrm{H}_{0}$ is rejected, $\mathrm{H}_{\mathrm{a}}$ is accepted or independent variable of linear regression model is able to explain the dependent variable $(\mathrm{Y})$

2. Significant Value $>\alpha 0.05$ then $\mathrm{H}_{0}$ is accepted, $\mathrm{H}_{\mathrm{a}}$ is rejected or the independent variable of the linear regression model is not able to explain the dependent variable $(\mathrm{Y})$

From the ANOVA table above, the results of the hypothesis test are simultaneously obtained with a calculated $F$ value of 61,643 with a significant level of 0.00 . Less than 0.05 , which means facing simultaneous significant influence between training (X1), promotion (X2) and mutation (X3) on employee performance (Y).

\section{Determination Test of $\mathbf{R} \& \mathbf{R}^{2}$}

Summary ${ }^{B}$

\begin{tabular}{|c|r|c|c|c|}
\hline ModelModel & $\mathrm{R}$ & $\mathrm{R}$ Square & $\begin{array}{c}\text { Adjusted R } \\
\text { Square }\end{array}$ & $\begin{array}{c}\text { Std. Error of the } \\
\text { Estimate }\end{array}$ \\
\hline dimension0 1 & $.895^{\mathrm{A}}$ & .788 .69667 & & .801 \\
\hline
\end{tabular}

a. Predictors: (Constant), Mutations, Promotion_ position, Training

b. Dependent Variable: Kinerja_karyawan

Based on the results of the test data in the table summary model, obtained an adjusted R square value of 0.801, which means the combination of training variables (X1), promotion (X2) and mutation (X3) affect employee performance (Y) discussed in this research. 


\section{CONCLUSIONS AND SUGGESTIONS}

\section{Conclusions}

Based on research on the analysis of the effect of training, job promotion and mutations on the performance of employees of PT. Transfashion Indonesia in Surabaya. Can be drawn The conclusions from this study are as follows:

1. Training, Job Promotion and Mutations simultaneously have a positive effect on the performance of employees of PT. Transfashion Indonesia.

2. Training has a partial effect on the performance of employees of PT. Transfashion Indonesia.

3. Job promotion has a partial effect on the performance of employees of PT. Transfashion Indonesia.

4. Mutations have a partial effect on the performance of employees of PT. Transfashion Indonesia.

5. From the results of the determination test it is known that Training, Job Promotion and Mutations affect employee performance by 0.801 .

\section{Suggestion}

Based on the conclusions described above, the researcher will provide suggestions and input that need to be considered for the performance of the employees of PT. Transfashion indonesia in Surabaya so that there is an improvement for better condition.

\section{REFERENCES}

[1] Achmad, NK, \& Sriekaningsih, A. (2017). Effect of Mutation and Career Development on Performance through Work Motivation at the Class I Airport of Juwata Tarakan. Journal Research and Analysis: Economy, 27-39.

[2] Julianry, A., Syarief, R., \& Affandi, MJ (2017). Effect of Training and Motivation on Employee Performance and Organizational Performance of the Ministry of Communication and Information. Journal of Business and Management Applications, 3(2), 236-245. https://doi.org/10.17358/jabm.3.2.236

[3] Kasim, N., Adolfina, \& Tawas, HN (2017). Analysis of Training, Job Placement and Employee Mutation and Its Effect on Employee Job Satisfaction at Non-Medical Employees at RSUP PROF Dr. R. D Kandou Manado. EMBA Journal, 5(2), 725-733.

[4] Nugraha, MBI, \& Surya, IBK (2016). Effects of Compensation, Work Environment, and Job Promotion on Job Satisfaction. E-Journal of Management of Unud, 5(1), 59-87.

[5] Rinaldi, U., Sani, \& Martono. (2018). Mutation and Promotion System and ITS Relations to Employees' Performance and Job Performance of the West Kalimantan Immigration Office. Journal of Applied Management (JAM), 16(1).

[6] Rosa, FE (2017). Mutations Against Employee Performance at PT. Kereta Api Indonesia (Persero) Operational Area 1 Jakarta. Journal of Economics and Business, 1(1), 20-39. https://doi.org/10.22236/agregat

[7] Sabar, ND, Adolfina, \& Dotulong, LOH (2017). Effect of Position Promotion and Mutations on Employee Performance (Study at Regional Office Employees of the Directorate General of Treasury of North Sulawesi Province). EMBA Journal, 5(2), 404-413.

[8] Sarboini, S. (2016). Performance of Employees and Impact on Promotion of Position. Peuradeun Scientific Journal, 4(1), 103-114. https://doi.org/10.13140/RG.2.1.4158.5680 